\title{
ELLEN RICHARDS'S HOME ECONOMICS MOVEMENT AND THE BIRTH OF THE ECONOMICS OF CONSUMPTION
}

BY

\author{
DAVID PHILIPPY
}

\begin{abstract}
In 1899, MIT chemist Ellen H. Richards (1842-1911) instigated a series of annual "Lake Placid Conferences" (1899-1908) that became known as the foundation of the home economics movement. Richards's first interest was in improving the household's well-being by using sanitary and nutrition sciences, an objective that was passed on to the movement. However, by the 1920s, home economists rather identified their field of expertise as the "science of consumption," emphasizing the idea of "rational consumption." My aim in this article is to give an account of how this shift in focus came about, by telling the story of the home economics movement founded by Richards. I examine how the movement problematized consumption by highlighting its relationship, and perception of itself, regarding economics. I argue that the concept of consumption was central to the structuring of the movement from its beginning and allowed home economists to claim it as their field of expertise because, as they believed, economists were not addressing the issue.
\end{abstract}

\section{INTRODUCTION}

When American chemist Ellen H. Richards's (1842-1911) effort to improve people's living conditions began, it was not about helping them to consume wisely, and was even less about building a theory of consumption. Richards's objective was to purify the home from germs, "our cruelest enemies" (Richards 1910, p. 19). Yet, the home economics movement she founded at the turn of the twentieth century would shift its attention towards consumption in the marketplace, claiming that economists were ignoring the issue. This shift was so significant that most home economists would call their discipline "the science of ultimate consumption" by the mid-1920s. ${ }^{1}$ In 1923, two events made

\footnotetext{
David Philippy: Centre Walras-Pareto, Universite de Lausanne. I am grateful to my PhD supervisor Harro Maas, Cléo Chassonnery-Zaïgouche, and Philip Gerard for their valuable comments on earlier versions of this article. I also thank the two anonymous referees for their careful reading and useful suggestions. Corresponding author. E-mail: David.philippy@gmail.com.

1 “Editorial," Journal of Home Economics 19, 4 (1927): 207.
}

ISSN 1053-8372 print; ISSN 1469-9656 online/21/03000378-400 @ The Author(s), 2021. Published by Cambridge University Press on behalf of The History of Economics Society. This is an Open Access article, distributed under the terms of the Creative Commons Attribution licence (http://creativecommons.org/licenses/by/4.0/), which permits unrestricted re-use, distribution, and reproduction in any medium, provided the original work is properly cited. 
home economists' expertise in consumption particularly visible: the publication of Hazel Kyrk's Theory of Consumption, and the creation of the Bureau of Home Economics in the US Department of Agriculture. While the first is recognized as the foundation of the economics of consumption (Kiss and Beller 2000; van Velzen 2001, 2003; Dimand and Lobdell 2008), the second is associated with the movement's orientation toward applied science, which promoted the idea of "rational consumption" (Goldstein 2012). These two landmarks represented the two sides-one theoretical and one applied - of the answer home economists formulated to the issue of addressing consumption. My aim in this article is to give an historical account of how this answer came about, by telling the story of the home economics movement founded by Richards.

Home economics is a neglected field in the history of economics. ${ }^{2}$ It is often said that it deals only with household problems, which are of no concern to economists. But the applied work of home economists in the 1920s and 1930s (notably at the Bureau of Home Economics and at the Bureau of Labor Statistics) would provide economists in the wake of World War II with substantial empirical materials and new insights into family budgets and consumption behavior. It is now well established that, for example, Milton Friedman and Franco Modigliani drew their hypotheses on the consumption function directly from home economist Margaret Reid's distinction between "permanent" and "transitory" income (see Forget 2000; Trezzini 2012, 2016; Yi 1996). Similarly, Gary Becker acknowledged the importance of Margaret Reid and her mentor Hazel Kyrk for his own work at the University of Chicago (see Cicarelli and Cicarelli 2003, p. 101; Grossbard-Shechtman 2001).

The main motivation for this article is that the home economists' understanding of consumption is crucial to a proper historical account of the economics of consumption in the United States. In order to address this issue, I examine how the home economics movement problematized consumption, by emphasizing its relationship, and perception of itself, regarding economics. I argue that consumption was a central subject in the structuring of the movement and allowed home economists to claim it as their field of expertise. Although Richards was not an economist herself, ${ }^{3}$ her work and the history of the movement she founded tell us about consumption as an object studied by women who identified themselves as the true heirs of economics as originally defined, in contrast with political economists, who were characterized as "usurpers." Ultimately, this work sheds some new light on the history of the analysis of consumption in American thought by highlighting the contribution of home economists.

At this point, some clarification of what I mean by "home economics" is necessary. The different terms used for it (household arts, domestic arts, domestic science, home economics, household economics, etc.) reflect the transformations and disputes within a domain of knowledge that in the United States goes back to at least the early nineteenth century. In this article, I draw a clear distinction between "domestic advice" ${ }^{4}$ literature

\footnotetext{
${ }^{2}$ Among the few exceptions, see notably, Becchio (2020), Forget (2011), Hirschfeld (1997), Le Tollec (2020), Pietrykowski (2009), Stapleford (2004), and Trezzini (2016).

${ }^{3}$ Home economist Cora M. Winchell referred to her in a tribute article as "Mrs. Richards the homemaker, scientist, and economist, [who] therefore, will always be associated in our thoughts with the founding of the home economics movement in America" (Winchell 1925, p. 715).

${ }^{4}$ I borrow the term from Sarah Leavitt's book From Catharine Beecher to Martha Stewart: A Cultural History of Domestic Advice (2002).
} 
and the micro-economic analysis of the household associated with the neoclassical theory of marriage of Charlotte D. Phelps (born in 1933), or the new home economics of Gary S. Becker (1930-2014) and Jacob Mincer (1922-2006), which started in the 1960s. Although this school clearly drew inspiration from pre-WWII female home economists, I argue that the purpose of their analysis was radically different from that of the preWWII analyses. Becker's objective was to study a domain - the household—with the tools and methods of microeconomics. Home economists before 1950, however, were analyzing consumption practices in order to raise consumers' standards of living. The distinction entails a radically different view on consumer preferences-that is, for (neoclassical) economists they are given, while for home economists the issue was exactly how they are formed and can be molded. Hence, I place new home economics outside the scope of the present analysis.

In the historiography of "domestic advice," the turn of the twentieth century and its association with the founding of the home economics movement is often held to be the most significant milestone (see, e.g., Sklar 1976; Stage and Vincenti 1997). Until the 1880 s, domestic advice had existed almost solely in the teaching of a few reference domestic manuals. Through the movement Richards founded, however, it became an organized nationwide network that would shift its attention towards consumption. I identify three distinct trends in the history of domestic advice in the United States: (1) the pioneer works written between 1820 and 1880, associated, for example, with Lydia Maria Child's American Frugal Housewife (1828) and Catharine Beecher's Treatise on Domestic Economy for the Use of Young Ladies at Home $(1841) ;{ }^{5}$ (2) the first generation of home economists (1890s to 1910s), which started with Richards and the movement she founded; ${ }^{6}$ and (3) the second generation (1920s to 1940 s), associated with a figure such as Hazel Kyrk (1886-1957).

These three groups never had clearly defined boundaries, and neither did they speak with a single voice, but all of them addressed the issue of improving the household's well-being. The first emphasized the teaching of morality to young girls; the second focused on scientific methods; and the third made better consumer choices its main objective. In this article, I focus on the last two, for they represent the particular moment when home economists turned their attention in the direction of consumption, claiming that economists were not addressing the issue.

The founding moment in the history of the home economics movement was the "Lake Placid Conferences on Home Economics" organized by Richards between 1899 and 1908. These conferences mainly attracted women from diverse professions (teachers, nutritionists, administrators, etc.) but who all shared the aim of making housework and the teaching of it more scientific and more efficient. By the 1920s, the movement had grown to maturity and became institutionalized, among other institutions, through the Bureau of Home Economics, which was created in 1923 in the US Department of Agriculture. The movement shifted its focus from the sanitary sciences to consumption,

\footnotetext{
${ }^{5}$ From the 1820 s to the 1880 s, many female novelists often included domestic advice in their work, as part of a general moral education. Therefore, a large portion of domestic advice literature can be found in novels that used sentimental stories to engage the reader. See Leavitt (2002, pp. 8-39).

${ }^{6}$ Here, I use historian Carolyn Goldstein's (2012, see pp. 2-3, 60-61) distinction between the first and second generation of home economists.
} 
notably by conducting large-scale budget studies and product testing. In 1925, bureau home economist Hildegarde Kneeland (1889-1994) recalled:

$[\mathrm{P}]$ roblems of consumption. How little this phrase conveys to the mind of most people was recently revealed most amusingly when an 'average consumer,' hearing that the writer was interested in the economics of consumption inquired, 'And how did you become interested in tuberculosis?' To home economists consumption does not mean tuberculosis. (Kneeland 1925, p. 16)

Eventually, by the 1930s, the work of home economists became essentially applied and was associated with an expertise that advocated "rational consumption" (Goldstein 2012). This paper is organized as follows. Section II briefly presents the origins of Richards's endeavor (1870s to the 1890s). It shows how she shifted her attention from sanitary sciences to home economics and ultimately to consumption. By the end of the 1890s, Richards understood that an increasing number of goods were now produced in the market, making their creation in the home obsolete. Thus, housewives were increasingly in need of assistance on how to spend their money in the marketplace. Richards did not find much help on this from the theories of economists. How, then, did economists theorize consumption at the time? With this question in mind, section III investigates the problematic status of consumption in the early years of the American Economic Association in the late 1880s. Discussions in the Committee on Questions of Economic Theory led by John B. Clark indicate that economists remained undecided about the place that consumption should have in economic analysis. In section IV, I show how this dormant state of consumption in economic analysis became an opportunity for the home economics movement. More specifically, I explain how Richards took her ambition to the next level through the Lake Placid conferences (1899 to 1908) and how the movement started to identify itself with the economics of consumption. I scrutinize discussions during the conferences about the name and position of home economics in the Dewey classification, and show that the movement identified itself with the ancient definition of economics, i.e., the administration of the home, in which spending activities were now significant. Section V then turns to the second generation of home economists and shows how they put the first generation's agenda on consumption into practice. To do so, I offer an overview of Hazel Kyrk's Theory of Consumption (1923) and of the applied work at the Bureau of Home Economics. The final section offers some concluding remarks.

\section{FROM SANITARY SCIENCE TO HOME ECONOMICS (1870s-1890s)}

Ellen Richards's maiden name was Ellen Swallow. She graduated in 1870 from Vassar College, ${ }^{7}$ a women's college in Poughkeepsie, New York State. The following year, she was admitted to the newly founded Massachusetts Institute of Technology (MIT) as a "special student" in chemistry, for women were not yet allowed to attend classes. In 1873 , she eventually succeeded in becoming the first woman to graduate from MIT. The

${ }^{7}$ Founded in 1861, Vassar was one of the "Seven Sisters," a group of women's colleges that sought to be the equivalent of Ivy League colleges for women (Chamberlain 1991, p. 110). 
same year, she received a master's degree in chemistry from Vassar College. In 1875, she married MIT professor of mining engineering Robert Richards, who had taught her mineralogy when she was a student. She wished to continue her studies at the doctoral level, but back then MIT was not awarding PhDs to women. Instead, in 1876, she convinced the faculty to open a department for women students where she could teach chemistry. This "Women's Laboratory" lasted until 1883, when women could finally join male students in the standard graduate program. She became appointed as an instructor in sanitary chemistry, a position she would hold until her death in 1911.8

Her course in sanitary chemistry at MIT was originally titled "Chemistry as Related to Vegetable and Animal Physiology." Richards put special emphasis on the relations of organisms to one another and to their environment (Swallow 2014, p. 69). ${ }^{9}$ Her shift in interest towards the household came gradually. From 1872 until 1882, the majority of her publications were on chemistry and mineralogy. ${ }^{10}$ During the 1880 s, she published mostly on sanitary sciences and food adulteration in relation to chemistry. In 1883, she published a small article in the New England Farmer on the general subject of domestic economy (Richards 1883). ${ }^{11}$ Four years later, she co-authored a book with the young home economist Marion Talbot (1858-1948) titled Home Sanitation: A Manual for Housekeepers (1887). After that, she wrote almost exclusively about nutrition, food, and home economics, reflecting on how studies in these areas could improve people's living conditions. ${ }^{12}$

Her work in hygiene and sanitary sciences was accompanied by a growing interest in family living conditions. Her starting point was that hygiene should be taught to avoid disease being spread by germs in the home. In Food Materials and their Adulterations (1898), Richards mentioned “The Germ Theory' of disease” (Richards 1898, p. 29). Indeed, research into micro-organisms had increasingly revealed that germs and dust could carry diseases - especially consumption and influenza - that might compromise health. Richards wrote at a moment of a "national crusade" against those diseases in the United States (Tomes 1997, p. 36), which led her to declare "war" against germs and

\footnotetext{
${ }^{8}$ For good biographical references, see Hunt (1912), Clarke (1973), Stage (1997b), Sutherland (2017), and Swallow (2014).

${ }^{9}$ This reference is drawn from The Remarkable Life and Career of Ellen Swallow Richards: Pioneer in Science and Technology (2014) by Pamela Swallow. It is not incidental that Swallow has Richards's maiden name: she is a descendant of Richards's uncle.

10 "Analysis of Samarskite from a New Locality" (1872); "Estimation of Vanadium in an Iron Ore from Cold Spring, N. Y.” (Vassar College thesis, 1873); "Accompanying the Lead Ore of Newburyport" (1875); "Notes on Some Sulpharsenites and Sulphantimonites from Colorado" (MIT thesis, 1878); "A New and Ready Method for the Estimation of Nickel in Pyrrhotites and Mattes" (co-authored, 1877); "Notes on Antimony Tannate" (co-authored, 1878); "The Adulteration of Groceries of Massachusetts" (1880); The Chemistry of Cooking and Cleaning: A Manual for Housekeepers (1882); First Lesson in Minerals (1882); "Notes on Some Reactions of Titanium" (1882).

${ }^{11}$ Richards's article was the first of a ten-article series titled "Science for the Housekeepers," which were written by different home economists between March and May 1883 in the New England Farmer.

${ }^{12}$ Richards was known for The Cost of Living as Modified by Sanitary Science (1899), The Cost of Food: A Study in Dietaries (1901), The Cost of Shelter (1905), Sanitation in Daily Life (1907), Chemistry in Cooking and Cleaning (co-authored, 1907), and her famous Euthenics: The Science of Controllable Environment (1910). Richards also published in various journals, mostly in the Tech Quarterly, the American Journal of Science and Arts, the American Kitchen Magazine, and of course the Journal of Home Economics at the end of her life, but she also published several papers in the Journal of American Chemical Society, the New England Farmer, the Journal of the Franklin Institute, and the Outlook.
} 
dust: "Dirt means disease, therefore the warfare with dirt is incessant" (Richards 1899, p. 106). These endeavors came to embody a wider project that would deal with the improvement of the housewife's practices in the home: health through sanitary sciences or cooking through nutrition science, for example. ${ }^{13}$ However, her vision of home economics was a scientific endeavor that aimed at social progress, not merely improving household tasks. Richards conceived of the home as the central nexus of change, and saw it as having national significance. The household was "the unit of social progress.... the home is the nursery of the citizen" (Richards 1899, p. 5). In this process of human betterment, women were central. Richards identified two different channels through which women's importance could be recognized. The first was their participation in the advancement of science: women were just as qualified as men, and the underutilization of their capacity was wasteful to scientific progress. The second was through their role as head of the household and their responsibility for child rearing, and hence for the health and well-being of future citizens. The improvement of the environment-that is, the home-in which children were reared was a national responsibility. This responsibility was in women's hands.

Richards's general vision was encapsulated in the term "euthenics"14 that she coined in reference to the then popular eugenics. The term broadly referred to an "art of better living," which was identified as home economists' progressive mission. By contrast with eugenics, euthenics aimed at bettering the living conditions of present generations: "Euthenics precedes eugenics, developing better men now, and thus inevitably creating a better race of men in the future. Euthenics is the term proposed for the preliminary science on which Eugenics must be based" (Richards 1910, p. viii). ${ }^{15}$ Clearly inspired by Richards's background in chemistry, the major assumption behind euthenics was that individuals were interacting with and shaped by their environment. Therefore, a modification in this environment would have consequences on the individual. Such consequences could be conveyed to the next generation, because acquired traits could be transmitted-presumably through education. The relation of individuals to their environment was therefore of central importance, for both present and future generations: "euthenics deals with race improvement through environment" (Richards 1910, p. viii).

By the end of the nineteenth century, housework in the United States was transformed by the supply of manufactured goods that had formerly been produced in the household (see Gordon 2016; Witkowski 2018). This shift meant that an increasingly large part of

\footnotetext{
${ }^{13}$ In 1890, Richards set up with Mary H. Abel the New England Kitchen, an experimental kitchen model that sought dietary reform by proposing nutritious and inexpensive meals. This kitchen model became the "Rumford Kitchen" in 1893 during the Columbia World Fair held in Chicago (see Levenstein 1980; Williams 2019).

14 "Euthenia" was the Greek goddess of prosperity. In the foreword of her book Euthenics: The Science of Controllable Environment (1910), published a year before her death, Richards gave the etymological origin

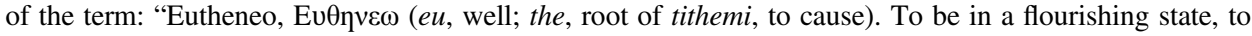
abound in, to prosper-Demosthenes. To be strong or vigorous-Herodotus. To be vigorous in bodyAristotle. Euthenia, Ev $\theta \eta v \imath \alpha$. Good state of the body: prosperity, good fortune, abundance-Herodotus" (Richards 1910, p. vii). The term was officially proposed by Richards during the sixth Lake Placid conference in 1904, during discussions on the name of the movement (Lake Placid Conference, Proceedings, Sixth Conference, 1904, p. 63), but its first published appearance was in her book The Cost of Shelter (1905).

${ }^{15}$ Richards's position regarding eugenics is sometimes unclear because her critique did not seem to be based on ethical grounds. On two contrasted views on Richards's euthenics, see Egan (2011) and Sutherland (2017).
} 
what had been included in housework was replaced by goods bought in the marketplace -e.g., soap, food, ready-made clothes. ${ }^{16}$ The home changed from a site of production to one of consumption. Richards clearly perceived this change: "The home has ceased to be the glowing centre of production from which radiate all desirable goods, and has become but a pool toward which products made in other places flow-a place of consumption, not of production" (Richards 1899, p. 23).

This shift entailed a need to analyze consumption practices, and eventually to make recommendations regarding "wise consumption." Richards did not find such an analysis in the work of political economists. ${ }^{17}$ As she argued in 1911:

Political economists have usurped the word [economics] to mean production of wealth. In early times this was largely done within the domain of the household, but with the taking away of the producing interest through the rise of factory products, a gap was left in the carrying out of this theory, only now beginning to be filled by the new science, the economics of consumption. (Richards 1911, p. 117)

Richards never named any economist specifically in her criticism. Although she did read some of them, she probably lacked sufficient knowledge of the economics literature to clearly identify which economists she was targeting. Richards essentially approached consumption studies through her "suggested budgets" that sought to help housewives allocate their expenditures in accordance to their level of earnings (see, e.g., Richards 1899 , p. 39). Nevertheless, in the 1920s, the second generation of home economists, mostly educated in economics, explicitly targeted the marginalists. In 1900, William Allen argued in the Journal of Political Economy that Ellen Richards's book The Cost of Living (1899) strengthened "the theory of eminent economists [presumably like Patten] [and] that the time has come for social philosophy to give more attention to problems of consumption" (Allen 1900, p. 270). The next section examines briefly the resources on which American home economists drew for their analysis of consumption.

\section{THE AMBIVALENT STATUS OF CONSUMPTION (1885-1891)}

In order to grasp fully what was at stake when Richards and later home economists presented themselves as the true heirs of the ancient definition of "economics," we need to elucidate the place of consumption in the economic discipline. By the 1880s, Simon Patten had engaged with consumption in The Consumption of Wealth (1889), and a decade later Thorstein Veblen did so, notably in his famous Theory of the Leisure Class (1899). Home economists were highly influenced by those two authors. Patten's original work opened the way toward an analysis of consumption that was distinct from

\footnotetext{
${ }^{16}$ Ready-made clothes at that time were essentially men's clothing, for until the 1930s most women's and children's clothing was still made in the home (see Gordon 2016, p. 43).

${ }^{17}$ Economist Simon N. Patten (1852-1922) is quoted a few times in her Cost of Living (1899, pp. 16, 52, 81, 92). Yet, the quotes never concerned his views on consumption, properly speaking, which were exposed in his Consumption of Wealth (Patten 1889). Rather, Richards exclusively referred to his book titled The Development of English Thought (Patten 1899) to support her general vision of progress. In line with Patten, she emphasized people's economic conditions and habits of thought. Two references to Thorstein Veblen's (1857-1929) theory of conspicuous consumption can also be found in her Cost of Shelter (1905, pp. 15-16).
} 
production, an analysis that would resonate with many aspects of home economists' work - on standards of living and waste, for example. As for Veblen, he was influential among second-generation home economists, who drew heavily on his theory of conspicuous consumption and on his instinct theory (see, e.g., Kyrk 1923). But there were not many other studies that home economists could rely upon. Though economists acknowledged its importance, methodological disputes kept consumption in a dormant position.

These disputes were caused by the ambiguous status of marginalism regarding consumption. On the one hand, marginalism in the 1880s furthered the analysis of consumption, allowing American economists to free themselves from classical political economy. By placing the consumer at the very beginning of the analysis, marginalism presented an important epistemological change from classical economics. On the other hand, marginalism was a target for a progressive critique that advocated the analysis of individuals' effective consumption. While marginalists considered individual preferences as fixed or given - thus, a feature of choice that need not be investigated for it is regarded as remaining outside the realm of economics-home economists made consumer expenditures and how preferences were formed the starting point of their analysis. The dividing line between these two theoretical positions separated "consumer theory" from the "study of consumer expenditures."

Deliberately or not, home economists at the turn of the twentieth century were ignoring the marginalist approach, thus favoring the second position. Judging from the reading lists that they provided during the Lake Placid conferences, they favored progressive economists such as Richard T. Ely, Simon Patten, and Thorstein Veblen.

American economists themselves recognized that they had undertaken a "practical excision" of consumption from economic analysis, as Francis A. Walker ([1883] 1896, p. 293) argued. During the last decade of the nineteenth century, voices of both economists and home economists deplored the absence of any discussion of consumption in economic analysis, even though they did not always understand consumption in the same way. However, both sides seemed to consider John S. Mill responsible for the absence of any discussion of consumption in classical economic analysis (see, e.g., Folwell 1889, p. 57; Kyrk 1923, p. 13). A common argument among American economists at that time to account for the absence of work on consumption was that such an investigation challenged the principle of consumer sovereignty. Amasa Walker (1799-1875) was one of the first American economists to argue that economics should pay more attention to consumption. For him, economists mistakenly considered that they should not "question [people's] wisdom" to choose (Walker 1866, p. 467). Hence, they wrongly saw no need to investigate consumption practices. ${ }^{18}$

By the 1870 s to the 1880 s, a new generation of American economists had emerged: the "new schoolers" (Dorfman 1955; Furner 1975, ch. 2). These young American economists (like Richard Ely, Simon Patten, or John B. Clark) had studied in Europe (mostly in Germany) and were taught along the lines of German historicism. Back in the United States, they criticized the "old schoolers" (like Simon Newcomb or James

\footnotetext{
${ }^{18}$ However, although his 1866 book The Science of Wealth certainly gave a larger place to consumption, it essentially consisted of the analysis of a phase - the destruction of wealth — of a general process, along with production, distribution, and exchange. In other words, consumption was still perceived as theoretically subordinated to production.
} 
L. Laughlin) dogmatic defense of laissez-faire. The conflict reached its peak in 1884, when it took the form of an "American Methodenstreit," leading to a fierce debate between Richard Ely and Simon Newcomb in the Johns Hopkins Studies in Historical and Political Science (Barber 2003, pp. 239-240). ${ }^{19}$ This conflict eventually led to the establishment of the American Economic Association in 1885.

During the third annual meeting of the association, held in 1889 in Philadelphia, new members joined the committee, and it was decided to explicitly reflect on the definition of the main terms and concepts of the discipline. ${ }^{20}$ The idea was to "tabulate in a compact form the various meanings that writers of eminence attach to the leading terms of economic science ... looking toward uniformity of definition" (Ely 1889, p. 63). The general idea was to clarify potential disagreements regarding the basic concepts of economics and to reinforce the discipline by speaking with a single voice.

Discussion of the definition of the term "consumption" led to a dispute about the relevance of the distinction between "productive" and "unproductive" consumption, popularized by John S. Mill in his Principles of Political Economy of 1848. In a nutshell, productive consumption is the type of consumption that allows the productive power of the economy to increase. For Mill, productive consumption appears when consumers "consume in keeping up or improving their health, strength, and capacities of work, or in raising other productive laborers to succeed them" (Mill [1848] 1963, p. 65). On the other hand, unproductive consumption was associated with "consumption on pleasures and luxuries" (p. 65). While, in the committee, some, such as Stuart Wood, still supported this distinction, two other committee members, George Gunton and Frederick B. Hawley, considered it a source of great confusion (Dorfman 1949, p. 209). John B. Clark attempted to mediate between both extreme positions, by arguing for a separation between theory and facts:

Are the men who say that consumption is not a part of the science of Political Economy and those who say that it is the most important in reality widely separated in thought? Do not the former mean that it is not a subject of research and the latter that it is among the most important data? Is it difficult to place beyond controversy the extent to which the consuming process lies within the field of research? Ought not the terms 'productive' and 'unproductive' consumption be put through a course of criticism? (Letter from Clark to Folwell, cited by Dorfman 1949, p. 209)

Clark's view distinguished the possibility of a research field dedicated to consumption from the relevance of the data associated with the study of consumption. It revealed the difficulty of reconciling the deductivist methodology inherited from the English school with an empirically based methodology that would have been suited to analyze consumption data. As it was understood at that time by the members of the committee,

\footnotetext{
${ }^{19}$ Although, as Yonay (1998, p. 41) showed it, the case of John B. Clark indicates that the situation was more complex than a mere conflict in method. Clark studied in Germany and clearly belonged to this new generation, but he was also the main figure of American marginalism by the turn of the century. Thus, this new generation encompassed both historicism and marginalism, and criticized what they perceived as a dogmatic defense of laissez-faire by the classics.

20 Those new members were Franklin H. Giddings, William W. Folwell, Charles A. Tuttle, George Gunton, and Stuart Wood. See the "Constitution, By-Laws and Resolutions" printed by the American Economic Association (1889, p. 11).
} 
studying consumption meant more than just widening the scope of economics to cover another subject. It entailed an epistemological transformation of the analysis, by making the consumer its point of departure. The development of marginalism was one expression of this inversion.

Clark's committee report was published in 1891 in the Publications of the American Economic Association (Clark 1891). Its tone contrasted with the initial aim of the committee toward clarification and uniformity. The original concept of "tabulating" the definitions of the discipline's main concepts was replaced by the production of a three-page report that confined itself to explaining how discord brought about evolutionary benefits for the discipline: "Where varying usages exist, a natural selection must determine which is to survive" (Clark 1891, p. 50). Thus, this episode shows that American economists did not completely ignore consumption but had different views about how it should be studied, which ultimately led to a status quo concerning the possibility of its study. This left room for the home economics movement to claim the field of consumption as its domain of expertise.

\section{FOUNDING THE HOME ECONOMICS MOVEMENT}

\section{The Lake Placid Conferences Cycle (1899-1908)}

In the late 1890s, Richards realized that the professionalization of household knowledge along the lines she envisaged was at odds with the goals of the already existing National Household Economics Association created in 1893 during the Universal Exposition in Chicago. ${ }^{21}$ Despite the very similar goals, Richards reproached this new association that it limited its goals to the improvement of the work done by domestic servants. ${ }^{22}$ Instead, Richard had in mind the establishment of a wide national network for the development of research into and teaching of home economics to women. When she was invited to give a talk on home management in 1898, she took the chance to turn her ideas into a movement.

Richards was invited by Annie G. Dewey (1850-1922) and Melvil Dewey (18511931) to the Lake Placid Club, a resort they had founded in upstate New York, just across Lake Mirror. The Deweys organized this resort as a "cooperative summer and winter home" for its members. ${ }^{23}$ Before the couple created this social club, Melvil Dewey had been the head of the State Library of New York and one of the founders of the American

\footnotetext{
${ }^{21}$ As Weigley (1974, p. 82) indicates, this organization was initiated by the Women's Congress during the exposition. Home economist Laura S. Wilkinson was the first president of the association and related the organization's three general aims in a report published in the American Kitchen Magazine as follows: "1. To awaken the public mind to the importance of establishing bureaus of information where there can be an exchange of wants and needs between employer and employed, in every department of home and social life. 2. To promote among members knowledge of the economic value of various foods and fuels; a more intelligent understanding of correct plumbing and drainage in our homes, as well as need for pure water and good light in a sanitarily built house. 3. To secure skilled labor in every department in our homes, and to organize Schools of Household Science and Service" (Wilkinson 1895, p. 133).

${ }^{22}$ This is what was known as "the servant problem" (see Addams 1903; Stage 1997b, p. 25).

${ }^{23}$ Lake Placid Club Leaflet, 1920, p. 3, https://archive.org/details/lakeplacidclubco00lake/page/n0 (accessed April 21, 2021).
} 
Library Association in 1876. Annie Dewey proved very enthusiastic about Richards's ideas, and together they decided to organize a conference on the subject at the Lake Placid Club the following year. This conference was the beginning of a series of annual conferences that became known as the "Lake Placid Conferences Cycle" (1899-1908), which proved foundational for the home economics movement.

The first conference took place in September 1899 and gathered eleven people (including Richards and the Dewey couple). The eight female participants were affiliated to organizations that showed a keen interest in food, cooking, and nutrition. ${ }^{24}$ The following events of the conference gathered an increasing audience, reaching its attendance pinnacle in 1908 (74 people). The same year, the Lake Placid Club counted 201 registered members, $95 \%$ of whom were women. ${ }^{25}$ As the event grew, it continued to gather teachers, home economists, nutritionists, and administrative experts. At the first conference, the participants were exclusively from New York State and Massachusetts. But through the years, the conference attracted people from other states in the country (Missouri, Washington, Illinois, etc.), from Canada (Toronto and other places in Ontario), and on several occasions even a participant from Great Britain.

Richards's conference attracted many supporters, and she made friends who would prove to be important allies. Among them was the chemist and pioneer nutritionist Wilbur O. Atwater (1844-1907), who imported the calorie measurement system into the United States. Atwater was inspired by Richards's work, and his own studies on food chemistry enhanced the movement's scientific credentials and expanded its legitimacy (Cravens 1990). The conference functioned as a rallying point against the National Household Economics Association and by 1908 had managed to supplant its competitor as home economists' primary organization. The tenth conference in 1908 was the last of the cycle, being replaced by the founding of the American Home Economics Association, with Richards as its president for the first two years. The following year, in 1909, Richards founded the Journal of Home Economics, which was created to diffuse and carry on her message, as the editorial of the first issue explained:

The Association has for its purpose, according to the constitution, "the improvement of living conditions in the home, the institutional household and the community"... [A]s a professional journal it should, first of all, print original articles both on the theoretical side of the household arts and sciences and in the applied fields, whether of education, or of practical work in the home, the institution and the community. (Journal of Home Economics 1909, p. 1)

The creation of the journal was a milestone for the movement's development. It enabled this first generation of home economists to give voice to their actions and their meetings, and to spread new ideas through a professional network.

\footnotetext{
${ }^{24}$ They were: Anna Barrows (editor of the American Kitchen Magazine, Boston), Maria Daniell (lecturer on foods and their preparation, Boston), Emily Huntington (New York cooking school), Mrs. Williams V. Kellen (who had introduced the school lunch program in Boston schools), Louisa A. Nicholass (State Normal School, Framingham), Alice Peloubet Norton (supervisor of domestic science, Brookline schools), Maria Parloa (pioneer in cookery teaching, New York), and Mrs. William G. Shailer (president of the New York Household Economic Association).

${ }^{25}$ See Lake Placid Conference on Home Economics (1901-1908), Proceedings. Proceedings of the ten conferences are available online at: https://digital.library.cornell.edu/catalog/hearth6060826 (accessed May $10,2021)$.
} 
The movement Richards had founded was also intended as a means for educated women to secure academic positions and eventually positions in industry (Stage 1997a, p. 5). In order to promote home economics teaching, members designed syllabi of courses, and the movement successfully convinced many schools to open home economics classes. ${ }^{26}$ This endeavor was closely monitored during subsequent annual conferences, as the different committees on courses indicate. ${ }^{27}$ The movement was on track, thanks to its "prophet," as Richards was referred to in home economist Isabel Bevier's book Home Economics in Education (1924).

During the 1910s, home economics courses began to be taught around the country, from elementary school to universities, gaining support from the government, which passed two crucial federal acts for the movement: the Smith-Lever Act (1914), intended to spread knowledge of home economics and agriculture to rural populations through the establishment of cooperative extension services; ${ }^{28}$ and the Smith-Hughes Act (1917), which aimed to promote vocational education in agriculture and home economics. However, those two Acts may have had a negative effect on the movement in the long run because they tended to confine home economics to rural life and vocational training, when the country was shifting to urban life and "pure research" in universities (Stage 1997a, pp. 9-10). ${ }^{29}$

But home economists became less focused on sanitation, because such expertise was less needed, thanks both to their work and to the general improvement in people's living conditions. Thus, as historian Nancy Tomes argues, "[b]y the late 1920s, heart diseases and cancer had replaced tuberculosis, influenza, and pneumonia as the leading causes of death" (Tomes 1997, p. 50). Home economists' role in the diffusion of knowledge about sanitation and cleanliness was crucial for improving living conditions at the turn of the century in the United States, but quickly degenerated to "a vague conviction that cleanliness promoted health" (Tomes 1997, p. 50).

\section{An Art or a Science? Naming and Classifying Home Economics}

In this subsection, I examine home economists' perception of themselves in relation to economics. I argue that the defining and naming of the academic discipline as "home

\footnotetext{
${ }^{26}$ See the reports on home economics teaching in the proceedings of the conferences. However, despite these successes, home economics never really managed to obtain the academic status Richards envisioned in universities (Stage 1997a, p. 8).

${ }^{27}$ Such monitoring was also directed to places outside the United States, as Englishwoman Alice Ravenhill revealed in her communication titled "Progress of Home Economics in England": "Mrs Richards has askt [sic] me to send a few words with reference to progress in England during the past 12 months" (Lake Placid Conference, Proceedings, Eighth Conference, 1906, p. 116).

${ }^{28}$ The role of those services was to channel useful and innovative practices for farmers. Such research originated from the new system of land-grant universities that was established in 1862 by the Morrill Land Grant Act, which awarded acres of land to states to fund public institutions. For those universities, the objective was to stimulate applied research in agriculture and mechanical work (see Mattingly 2017, esp. ch. 5).

${ }^{29}$ Nevertheless, as thoughtfully suggested by one of the reviewers, by promoting the teaching of home economics as a vocational subject, the Smith-Hughes Act created opportunities for rural women to pursue higher education. In this respect, home economics allowed many farm girls to enter teacher's colleges, which led some of them on an academic path, especially in land-grant universities.
} 
economics" during the annual Lake Placid conferences contributed to home economists' identification with the field of consumption.

Here is how they defined the subject at the first conference: "After full discussion the name 'Home economics' was agreed on as the title preferable for the whole general subject and it was determined to consider it a distinct section of the general subject of economics" (Lake Placid Conference, Proceedings, First Conference, 1899, pp. 4-5). Discussions about the name would recur during the following conferences, but the chief ambition was to connect home economics with economics. During the first years, participants agreed to say that home economics should be understood as a subdiscipline of the general field of economics. The term "economics" was used because it referred to what home economics was considered to be about: the proper administration of the home. As home economist Caroline Hunt argued in her biography of Richards (1912, p. 268):

the name adopted by the Lake Placid Conference after much thought and a full discussion [was] home economics: home meaning the place for the shelter and nurture of children or for the development of self-sacrificing qualities and of strength to meet the world; economics meaning the management of this home on economic lines as to time and energy as well as to money.

Discussions on the definition of the field were continued by the work of the "Classification Committee," 30 formed during the first conference to situate home economics in the Dewey Decimal Classification. ${ }^{31}$ Reports and discussions over home economics' place in the classification indicate that the movement sought to become a sound academic discipline and to send a message on its position in relation to economics.

As Anne Fields and Tschera Connell (2004) have shown, the debates over the classification report written by Annie Dewey, Myrtilla Avery, and Mary W. Plummer were about the choice between two distinct fields, represented in the classification by subdivision 339 (economics of consumption) and subdivision 640 (domestic economy); the former belonged to the general division "Sociology" (300) and came under the section "Political Economy" (330), and the latter belonged to the general division "Useful Arts" (600). The committee's proposal placed home economics under subdivision 339 (economics of consumption). For Fields and Connell (2004), this choice can be interpreted as a desire for home economics to be recognized as an academic field and to avoid confusion with "mere household arts," 32 which would have confined home economics to the old concept of domestic science. During the conference in 1908, Richards recalled this episode:

thus home economics was decided on as ethical rather than merely one of the useful arts as in the Dewey Decimal classification (640). This was economy of production. There

\footnotetext{
${ }^{30}$ The first committee included Annie Dewey, Myrtilla Avery, and Mary W. Plummer (Lake Placid Conference, Proceedings, First Conference, 1899, p. 8).

${ }^{31}$ Before Dewey's first classification system in 1876, libraries used fixed location systems that consisted of identifying the classification number with the physical location of the book. Dewey's system was a coherent classification system organized in ten classes, each divided into ten divisions, which were each divided into subdivisions, etc. Today, the Dewey Decimal Classification system is still the system adopted by most libraries.

${ }^{32}$ Lake Placid Conference, Proceedings, First Conference (1899, p. 4; quoted by Fields and Connell 2004).
} 
was no representation under ethics or science. What was needed was economy of consumption. In looking for a place in the classification, 339 was chosen. (Richards, in Lake Placid Conference, Proceedings, Tenth Conference, 1908, pp. 20-21)

Richards emphasized the necessity of encouraging the movement to analyze the formation of consumption habits and of distinguishing it from the nineteenth-century concept of domestic science, which was strongly associated with household production. ${ }^{33}$ Richards's positioning did not win unanimous support among members, and, when she purposefully absented herself from the fifth conference to put some distance between herself and the series of events, the "household art contingent mounted a rear-guard action" (Stage 1997a, p. 7). The variety of members from which the movement grew certainly led to disputes on the movement's aim, but it also reflected the transformation of home economics, even though Richards never ceased to be recognized as leader and prophet of the movement (Bevier 1911).

However, Melvil Dewey did not follow home economists' advice, and he left home economics within the "Useful Arts" division in his classification. As Laura Shapiro suggests, this choice was probably due to the inconvenience of listing all the subsections about food, for example, which "went on for pages" in a section dedicated to consumption (Shapiro [1986] 2009, p. 168).

At the sixth conference, someone ${ }^{34}$ reminded participants that "Dr Nicholas Murray Butler, president of Columbia university, said sometime ago: 'Why do you not take your name economics? It belongs to you, why don't you take it?' " (Lake Placid Conference, Proceedings, Sixth Conference, 1904, p. 63). This suggestion revealed the inclination among home economists to claim the field of consumption in discussions on the name of the discipline. For Richards and an increasing number of her followers, home economists were the true heirs of economics in its original meaning, implicitly referring to the ancient Greeks' definition. They were indeed suggesting what can be found in the work of Xenophon and Aristotle ('oikonomia' [oikovo $\mu$ í $\alpha$ ]): economics was about the administration of the home. In their view, political economists had appropriated this definition to mean production. In contrast, home economists should target the consumption of wealth in the household, which was part of home management.

Claiming "sovereignty" over consumption was certainly an attempt to position home economics among the various academic areas. Retrospectively, this strategy allowed home economists to pursue their initial aim of improving people's living conditions, as embodied in Richards's euthenics. Emphasizing consumption was thus perceived by the field as adaptation to the transformation of the production system. Besides, expanding their area of expertise also represented great career opportunities for this cohort of educated women trained in domestic sciences. Richards had perceived the demand that was emanating from the public and she believed that both housewives and professional home economists could benefit from it.

However, by the end of the Lake Placid conferences, the formation of consumption habits was still to be explored. Many home economists relayed Richards's eagerness to

\footnotetext{
${ }^{33}$ Although Richards rejected the old conception attached to domestic science, she actually favored the term "domestic science," for it emphasized the scientific endeavor of the movement. As for Atwater, he advocated the term "home science," rather than "home economics," which would have "left out the soul" (see Stage 1997a, pp. 5-6). On the various propositions for terms during the conferences, see Weigley (1974).

${ }^{34}$ The proceedings do not show who this person was.
} 
explore household consumption, but they still voiced the hope that economists could provide a theoretical analysis of consumption they could use for themselves. At the seventh conference, Susannah Usher called for "assistance from the chemist, physicist, physiologist and economist.... The economist can give us a theory of consumption" (Lake Placid Conference, Proceedings, Seventh Conference, 1905, p. 100). Yet, most of them remained unsatisfied with the few works economists were proposing. Veblen's theory certainly was a step in the right direction and would allow second-generation home economists to build on it, but it probably did not offer a framework that could be applied to household consumption. Veblen's work was not used by home economists for its broad theory: they used only portions of it. References to the theory of pecuniary emulation and to invidious comparison were most frequent in the Journal of Home Economics in the period from 1909 to 1920, but they were generally brought in as widely accepted evidence to support an argument, not used to build a theory of consumption.

\section{THE SCIENCE OF CONSUMPTION IN THE 1920s}

After Richards's death in 1911, the movement she founded continued its expansion and gained significant recognition from the public. In particular, home economists greatly benefited from the First World War. When the United States entered the conflict in 1917, Herbert Hoover saw the food problem as crucial and the movement as an opportunity to rationalize food supplies. Because of the recruitment of many women to the US Food Administration, where their expertise was used on food conservation, home economists' work on efficient diets became identified with patriotic values that helped emphasize the role of food preservation-saving food and eliminating waste-at home (see Sworakowski 1979, p. 42).

However, by the 1920s, home economists' expertise became explicitly associated with consumption. They were still recognized for their work on food studies and nutrition, but there was increasing demand for information regarding household equipment and products from the public (Goldstein 2012, pp. 64-65). In particular, the early 1920 s represent an important landmark in the history of home economics in relation to consumption. Between 1900 and 1920, most home economists' works on consumption emphasized the need for such studies rather than actually conducting them. By the 1920s, however, consumption had become an object of direct study by home economists, who drew inspiration from the research agenda laid by Richards and the first generation. In 1923, the publication of Hazel Kyrk's Theory of Consumption (1923) and the creation of the Bureau of Home Economics led home economists to embrace the analysis of consumption fully and meant that their claim to be experts in the field was recognized. While Kyrk built on an institutional framework to address the "problems of the consumer," the bureau conducted research on "rational consumption" in order to set standards for consumption. Here, I wish to make clear that my aim is not to compare in any way Kyrk's work with that of the bureau but rather to highlight the key methodological perspectives that emanated from each that allow us to have an understanding of what precisely analyzing consumption meant at that time. Using Kyrk and the bureau as key landmarks, the following subsections offer an overview of those two perspectivesthe theoretical and the applied—of what a "science of consumption" meant. 


\section{A Theory of Consumption}

The most important effort to theorize consumption economics was conducted by Hazel Kyrk. In her famous Theory of Consumption (1923), ${ }^{35}$ she analyzed consumption using an institutionalist approach (Kiss and Beller 2000; van Velzen 2001, 2003). Kyrk's theory is based on a critique of the theoretical stance adopted by marginalists, emphasizing that it overlooked the complexity and variety of factors involved in the formation of consumer's choice. Unlike most first-generation home economists such as Richards, Kyrk had graduated in economics, which allowed her to criticize marginalism on specific methodological points, such as their hedonistic psychology (Kyrk 1923, p. 17). Yet, she also acknowledged the marginalists' contribution to the study of consumption, which, unlike the English classical school, placed the consumer at the center of the analysis (Kyrk 1923, pp. 12-13). Still, for Kyrk, marginalism mistakenly considered that the consumer's goal could be understood in similar terms as those of the producer. In other words, the producer's objective - to make profit - could be applied to the consumer - to maximize utility. Drawing on Wesley Mitchell's article "The Backward Art of Spending Money" (1912), she argued that the consumer does not have as clearly defined objectives as the producer: " 'comfort,' 'convenience,' and 'well-being' are vague and undefined, if not undefinable, terms. It is difficult to carry out these purposes upon the market and express them in concrete goods" (Kyrk 1923, p. 188). Having acknowledged this flawed symmetrical reasoning, she developed a theory of consumer's behavior that emphasized, in addition to economic factors (such as consumer's income, price, monopoly power, etc.), the crucial role of social factors (e.g., scale of value, imitation, the role of advertising, standards of consumption). The core idea of Kyrk's theory of choice is based on the "valuation process," 36 that is, the cognitive process that leads consumers to give value to goods. Because such a valuation process is the result of social factors, consumer choice could not be explained as a process of optimization, as in hedonistic psychology; instincts, social values, and standards of consumption needed to be taken into consideration to fully address the consumer's problem.

In line with the American institutionalist movement, Kyrk's objective was not to build an abstract positivistic image of consumer behavior but to raise standards of living by focusing on the social factors involved in consumer's choice. Compared with earlier works on consumption economics, written by both economists and/or home economists, Kyrk's theory was a significant milestone. ${ }^{37}$ The interest aroused by Kyrk's book went beyond the realm of home economics. Several American male economists engaged in the economics of consumption, clearly drawing their inspiration from Kyrk and other

\footnotetext{
${ }^{35}$ Kyrk's Theory of Consumption was drawn from her doctoral thesis titled "The Consumer's Guidance of Economic Activity," defended at University of Chicago in 1920. For this work, she won the Hart, Schaffner and Marx Prize (see Madden 2018).

${ }^{36}$ A concept presumably drawn from John Dewey's similar notion, contained in Human Nature and Human Conduct (see van Velzen 2001, p. 24).

${ }^{37}$ Kyrk's academic affiliations are revealing in relation to her pivotal position for the discipline. She was a member of both the Department of Economics and the Department of Home Economics at the University of Chicago. However, it took several years for Kyrk to be officially appointed to the Department of Economics. When she arrived at Chicago in 1925, she accepted the position at the Department of Home Economics on the condition that she had a joint appointment with the Department of Economics. But she had to wait until 1929 to obtain full recognition (see Folbre 1998, pp. 47-48; see also the correspondences in Kiss and Beller 2000).
} 
home economists. ${ }^{38}$ Male economists interested in consumption drew heavily on the work of home economists, as Stuart Chase and consumer rights activist Frederick J. Schlink's Your Money's Worth (1927) shows. Paul Nystrom's Economic Principles of Consumption (1929) is another good illustration of work directly inspired by home economics, in which one can find multiple references to articles from the Journal of Home Economics and to Kyrk's book (see, e.g., Nystrom 1929, p. 70). Although Kyrk's book represented a major clarification of the terms in which consumption was articulated, it remained attached to a progressive endeavor, inherited from both the institutionalist movement and the first-generation home economists' agenda, that emphasized improvement in living conditions.

\section{The Applied Science of Consumption at the Bureau of Home Economics}

The Smith-Lever Act (1914) mentioned earlier had enabled the creation of cooperative extension services within the Department of Agriculture that would spread home economics knowledge through land-grant colleges. In 1915, the Office of Home Economics was created as a part of the US Department of Agriculture and, eight years after in 1923, this office was transformed into the Bureau of Home Economics by Secretary of Agriculture Henry C. Wallace. ${ }^{39}$ The bureau became one of the most important federal institutions for the diffusion of home economics knowledge. There, bureau home economists wrote leaflets and bulletins drawn from experiment stations research, product testing, large-scale budget studies, and social surveys they conducted, which were sent to universities, women's journals, and magazines all around the country. In this respect, the bureau held a crucial role in gathering, centralizing, and redistributing home economics knowledge across the country.

The bureau's initial mission, which was decided by the Congress, was to target rural populations to improve their living conditions, which had degraded over the last few years. Home economist Louise Stanley was appointed as first president of the bureau, a position she held until 1943. A few months after the bureau's creation, Stanley published in the Journal of Home Economics an article titled "Plans for the Bureau of Home Economics" (Stanley 1923), in which she emphasized her desire to study "[t]he most neglected [field] ... which has to do with the economic phases of the home" (p. 679). As in the last couple of decades, budget studies had demonstrated that food and clothing were among the main components of family spending (Stanley 1923, pp. 680-681), home economists could provide help on those particular topics. Initially, the bureau was subdivided into two divisions, Food and Nutrition and Economics, but in 1924 a Textiles and Clothing division was added. All three divisions shared the general aim of making housewives' practices more rational and establishing standards. At the end of the 1930s, Kyrk herself worked at the bureau as chief economist and made substantial contributions, notably through her participation on the Consumers Purchase Study, which was

\footnotetext{
${ }^{38}$ Notable books on the topic published after Kyrk's Theory of Consumption in the 1920s-1930s-written by both female home economists (e.g., Hoyt 1928; Reid 1938) and male economists (e.g., Waite 1928; Nystrom 1929) — can be found in Matherly's article "The Development of Consumer Economics" (1942).

${ }^{39}$ On the history of the bureau, see Betters (1930) and Goldstein (2012, esp. pp. 62-97). In addition, it is worth mentioning that an increasing number of home economists by the end of the 1920s and especially in the 1930s were working in the private sector, helping producers understand the tastes and needs of consumers (see Goldstein 2012, pp. 174-207).
} 
recognized as the bureau's most significant achievement (Stapleford 2007). During the 1920s, most budget studies conducted at the bureau were standard-of-living studies among farm families. ${ }^{40}$ In cooperation with the Bureau of Agricultural Economics, extension services, or land-grant universities, bureau home economists produced detailed studies that aimed to offer cost-of-living studies on farm families. Ultimately, such studies would serve to build "suggested" or "ideal" budgets in the same line as Richards. ${ }^{41}$ By 1930, bureau director Louise Stanley summed up the work that had already been done by the economics division since its creation under three categories: "[t]he studies of standards and cost of living previously undertaken include three groups of families-farm families, families of business and professional men living in cities, and families receiving mothers' pensions" (Bureau of Home Economics 1930, p. 7). By the end of the 1930s, it was clear that budget studies were focusing less on farm families and investigating the consumption patterns of middle-class urban population as well. Of course, food studies remained one of the key occupations of the bureau, with home economists conducting experiments to measure nutriments and calorie intake and designing recipes. However, Stanley believed that women as consumers were in need of assistance: "[a] more detailed study of the factors which enter into these costs should help women in determining clothing standards and expenditures, and to make intelligent choice" (Stanley 1923, p. 680). The need for standards, Stanley believed, was essential, because producers were not giving enough information on products-and especially on their quality. Stanley's objective was carried out by Hildegarde Kneeland, a former student of Hazel Kyrk at Chicago recruited to lead the economics division of the bureau. In line with Kyrk's opinion that consumers needed guidance, bureau home economists such as Kneeland devoted themselves to studying family incomes in order to set standards of consumption that would allow consumers to make "wise choices." In doing so, the bureau sought to address the needs and desires of an "average consumer," which equated to the figure of the modern American housewife (Goldstein 2012, pp. 134-135). However, by the 1930s, the bureau's mission became associated more with the role of an intermediary between producers and consumers, using its expertise to match supply with demand. The emphasis on educating consumers about advertising and helping them to choose among goods was replaced by an increasing role of shaping American consumer culture, acting as a way of informing producers of consumers' desires. In 1943, Stanley was replaced as bureau chief by a leading scientist in nutrition, Henry C. Sherman. The bureau was also renamed Bureau of Human Nutrition and Home Economics, a change that, as Carolyn Goldstein argues, "reflected a shift in the agency's emphasis from general consumption (covering topics such as textiles, appliances, and domestic budgets) to food and nutrition" (Goldstein 2012, p. 247). Throughout the 1940s and 1950s, the bureau lost much of its weight as a center of consumer expertise, and was gradually dismantled by the early 1960s.

Both Kyrk's Theory of Consumption and the work conducted at the Bureau of Home Economics represented crucial contributions to the understanding of consumption as an economic phenomenon. Following the agenda of first-generation home economists, this

\footnotetext{
${ }^{40}$ See, for example, the study "Family Living in Farm Homes" conducted jointly by the Bureau of Home Economics and the Bureau of Agricultural Economics (Kirkpatrick, Atwater, and Bailey 1924).

41 “'Suggested' budgets will be drawn up for farm families of varying size and income" (Bureau of Home Economics 1925, p. 16).
} 
second generation of home economists understood consumption as a key lever to improving people's living conditions and made the issue of standards their central concern. While Kyrk's work gave birth to the economics of consumption, the applied work conducted at the bureau contributed both to the gathering of empirical data about consumption practices and to the setting of standards in the context of the emerging consumer society.

\section{CONCLUSION}

The home economics movement tells us about the changing frontiers of American economics. Between 1880 and 1900, both economics and home economics were struggling to define themselves. Yet, the subject of consumption encapsulated both epistemological debates among economists and professional prospects for home economists.

Richards's work began with her fascination for the relationship between organisms and their environment. When her interest moved in the direction of home economics, she sought to improve people's living conditions through education in sanitary science at home, emphasizing the danger of "germs," and through the science of nutrition. But Richards had a keen eye for the transformation of women's work in the household. The increasing amount of manufactured goods available in the market made household spending a large and increasing responsibility of housewives. As she argued during the last Lake Placid conference, "The flow of industry has past [sic] on and left idle the loom in the attic, the soap kettle in the shed" (Richards, in Lake Placid Conference, Proceedings, Tenth Conference, 1908, p. 19). Richards emphasized the growing necessity to guide the housewife on spending activity, because her choice and utilization of goods affected the household's well-being. Economists were said to ignore the issue, adopting a definition of economics that left no room for a proper analysis of consumption practices; the consumer was considered autonomous and consumer preferences were taken as given.

The dormant position of consumption in economics left a niche for home economists. During the Lake Placid Conferences Cycle between 1899 and 1908, debates about the name and the position of home economics in the Dewey Classification reveal the movement's perception of itself. The movement put special emphasis on its relationship with the economics discipline, claiming its right to identify itself as that part of economics that was ignored by economists. That part would become defined as the science of "ultimate consumption," which was perceived as a normative and empirical subject of study. Home economists were-in Richards's words-entitled to "fill this gap" because they considered themselves the "true heirs" of the original meaning of the term "economics." In identifying themselves with economics, home economists structured their field in contrast to a science that ignored people's actual living conditions. First-generation home economists understood consumption as a key subject that required further investigation, for it was identified as one of the activities women were devoted to that affected the household's well-being. In this sense, "rational consumption" was really part of "rational living," as encapsulated in Richards's "euthenics." 
Thus, following Richards's vision after her death in 1911, home economics increasingly focused on consumption studies. In the United States, housework was being replaced by manufactured goods, and thus expertise in sanitary sciences and nutrition was being replaced by expertise in consumer goods. In 1923, the publication of Hazel Kyrk's Theory of Consumption and the creation of the Bureau of Home Economics led home economists to put the effort of Richards and the first generation of home economists on analyzing consumption into practice, thus strengthening their claim to be experts in the field. While Kyrk built on an institutional framework to address the "problems of the consumer," the bureau conducted research on "rational consumption" in order to set standards of consumption. Ultimately, each of them expressed one side of the dual view of what a "science of consumption" meant for home economists after Richards: an understanding of the true motives of choice and a progressive endeavor to better people's living conditions by improving the choices they make in the marketplace.

\section{REFERENCES}

Addams, Jane. 1903. "The Servant Problem.” Good Housekeeping 37 (September): 233-240.

Allen, William. 1900. "Review of The Cost of Living as Modified by Sanitary Science, by Ellen H. Richards." Journal of Political Economy 8 (2): 269-271.

American Economic Association. 1889. "Constitution, By-Laws and Resolutions of the American Economic Association with List of Officers and Members." Publications of the American Economic Association 4 (Suppl.): 1-28.

Barber, William. 2003. “American Economics to 1900.” In W. J. Samuels, J. Biddle, and J. B. Davis, eds., A Companion to the History of Economic Thought. Malden: Blackwell, pp. 231-245.

Becchio, Giandomenica. 2020. A History of Feminist and Gender Economics. New York: Routledge.

Beecher, Catharine E. 1841. A Treatise on Domestic Economy for the Use of Young Ladies at Home. Boston: T.H. Webb.

Betters, Paul V. 1930. The Bureau of Home Economics: Its History, Activities and Organization. Washington, DC: The Brookings Institution.

Bevier, Isabel. 1911. "Mrs. Richards' Relation to the Home Economics Movement." Journal of Home Economics 3 (3): 214-216.

- 1924. Home Economics in Education. Philadelphia: J.B. Lippincott Company.

Bureau of Home Economics. 1925. Report of the Chief of the Bureau of Home Economics. Washington, DC: United States Department of Agriculture, Bureau of Home Economics.

-1930. Report of the Chief of the Bureau of Home Economics. Washington, DC: United States Department of Agriculture, Bureau of Home Economics.

Chamberlain, Mariam K., ed. 1991. Women in Academe: Progress and Prospects. New York: Russell Sage Foundation.

Chase, Stuart, and Frederick J. Schlink. 1927. Your Money's Worth: A Study in the Waste of the Consumer's Dollar. New York: Macmillan.

Child, Lydia Maria. 1828. The Frugal Housewife: Dedicated to Those Who Are Not Ashamed of Economy. Boston: Marsh \& Capen and Carter \& Hendee.

Cicarelli, James, and Julianne Cicarelli. 2003. Distinguished Women Economists. Westport: Greenwood Publishing Group.

Clark, John B. 1891. "Report of the Committee.” Publications of the American Economic Association 6 (1/2): 49-51.

Clarke, Robert. 1973. Ellen Swallow: The Woman Who Founded Ecology. Chicago: Follett Publishing Company. 
Cravens, Hamilton. 1990. "Establishing the Science of Nutrition at the USDA: Ellen Swallow Richards and Her Allies.” Agricultural History 64 (2): 122-133.

Dimand, Robert W., and Richard A., Lobdell 2008. "Kyrk, Hazel (1886-1957).” In Steven N. Durlauf and Lawrence E. Blume, eds., The New Palgrave Dictionary of Economics (online).

Dorfman, Joseph. 1949. The Economic Mind in American Civilization. Volume 3, 1865-1918. New York: The Viking Press.

- 1955. "The Role of the German Historical School in American Economic Thought." The American Economic Review 45 (2): 17-28.

Egan, Kristen R. 2011. "Conservation and Cleanliness: Racial and Environmental Purity in Ellen Richards and Charlotte Perkins Gilman.” Women's Studies Quarterly 39 (3/4): 77-92.

Ely, Richard T. 1889. "Secretary's Report. Report of the Proceedings of the American Economic Association. Third Annual Meeting, Philadelphia, December 26-29." Publications of the American Economic Association 4 (4): 43-95.

Fields, Anne M., and Tschera Harkness Connell. 2004. "Classification and the Definition of a Discipline: The Dewey Decimal Classification and Home Economics.” Libraries \& Culture 39 (3): 245-259.

Folbre, Nancy. 1998. “The Sphere of Women' in Early-Twentieth-Century Economics.” In Helene Silverberg, ed., Gender and American Social Science: The Formative Years. Princeton: Princeton University Press, pp. 35-60.

Folwell, William W. 1889. "The Effect of Correct Analysis on Doctrine in Political Economy." Publications of the American Economic Association 4 (5): 55-69.

Forget, Evelyn L. 2000. "Margaret Gilpin Reid (1896-1991).” In R. W. Dimand, M. A. Dimand, and E. L. Forget, eds., A Biographical Dictionary of Women Economists. Cheltenham: Edward Elgar, pp. 357-362.

- 2011. "American Women and the Economics Profession in the Twentieth Century." Economia. History, Methodology, Philosophy 1 (1): 19-30.

Furner, Mary O. 1975. Advocacy and Objectivity: A Crisis in the Professionalization of American Social Science, 1865-1905. London: Routledge.

Goldstein, Carolyn M. 2012. Creating Consumers: Home Economists in Twentieth-Century America. Chapel Hill: University of North Carolina Press.

Gordon, Robert J. 2016. The Rise and Fall of American Growth: The U.S. Standard of Living Since the Civil War. Princeton: Princeton University Press.

Grossbard-Shechtman, Shoshana. 2001. "The New Home Economics at Colombia and Chicago." Feminist Economics 7 (3): 103-130.

Hirschfeld, Mary L. 1997. "Methodological Stance and Consumption Theory: A Lesson in Feminist Methodology." History of Political Economy 29 (Suppl. 1): 189-211.

Hoyt, Elizabeth E. 1928.The Consumption of Wealth. New York: Macmillan.

Hunt, Caroline L. 1912. The Life of Ellen H. Richards. Boston: Whitcomb \& Barrows.

Journal of Home Economics. 1909. “Announcement.” Journal of Home Economics 1 (1): 1-2.

-. 1927. "Editorial." Journal of Home Economics 19 (4): 207-214.

Kirkpatrick, Ellis L., Helen W. Atwater, and Ilena M. Bailey. 1924. Family Living in Farm Homes: An Economic Study of 402 Farm Families in Livingston County, N.Y. Department Bulletin No 1214. U.S. Dept. of Agriculture. http://archive.org/details/familylivinginfa1214kirk. Accessed 10 May, 2021.

Kiss, Elizabeth D., and Andrea H. Beller. 2000. "Hazel Kyrk: Putting the Economics into Home Economics." Kappa Omicron Nu Forum 11 (2): 25-42.

Kneeland, Hildegarde. 1925. "The Field of Research in the Economics of the Home." Journal of Home Economics 17 (1): 15-19.

Kyrk, Hazel. 1923. A Theory of Consumption. Boston and New York: Houghton Mifflin Company.

Lake Placid Conference on Home Economics. 1901-1908. Proceedings of the Lake Placid Conference (1899-1908). New York: Lake Placid Conference.

Leavitt, Sarah A. 2002. From Catharine Beecher to Martha Stewart: A Cultural History of Domestic Advice. Chapel Hill: University of North Carolina Press. 
Le Tollec, Agnès. 2020. "Finding a New Home (Economics): Towards a Science of the Rational Family, 1924-1981." PhD diss., Université Paris-Saclay.

Levenstein, Harvey. 1980. "The New England Kitchen and the Origins of Modern American Eating Habits." American Quarterly 32 (4): 369-386.

Madden, Kirsten. 2018. "Women Economists of Promise? Six Hart, Schaffner and Marx Prize Winners in the Early Twentieth Century." In Kirsten Madden and Robert W. Dimand, eds., Routledge Handbook of the History of Women's Economic Thought. London: Routledge, pp. 250-271.

Matherly, Walter J. 1942. "The Development of Consumer Economics." Southern Economic Journal 9 (1): 53-61.

Mattingly, Paul H. 2017. American Academic Cultures: A History of Higher Education. Chicago: University of Chicago Press.

Mill, John S. [1848] 1963. Collected Works of John Stuart Mill: Principles of Political Economy. Toronto: University of Toronto Press.

Mitchell, Wesley C. 1912. "The Backward Art of Spending Money." American Economic Review 2 (2): 269-281.

Nystrom, Paul H. 1929. Economic Principles of Consumption. New York: Ronald Press Company.

Patten, Simon N. 1889. The Consumption of Wealth. Philadelphia: Publications of the University of Pennsylvania.

- 1899. The Development of English Thought: A Study in the Economic Interpretation of History. New York \& London: Macmillan.

Pietrykowski, Bruce. 2009. The Political Economy of Consumer Behavior: Contesting Consumption. New York: Routledge.

Richards, Ellen H. S. 1883. "Science for Housekeepers-No 1. Domestic Economy." The New England Farmer, March 3.

- 1898. Food Materials and Their Adulterations. Boston: Home Science Publishing Co.

1899. The Cost of Living as Modified by Sanitary Science. New York: J. Wiley \& Sons.

1901. The Cost of Food: A Study in Dietaries. New York: J. Wiley \& Sons.

1905. The Cost of Shelter. New York: J. Wiley \& Sons.

1907. Sanitation in Daily Life. Boston: Whitcomb \& Barrows.

1910. Euthenics: The Science of Controllable Environment. Boston: Whitcomb \& Barrows.

1911. "The Social Significance of the Home Economics Movement." Journal of Home Economics 3 (2): 117-125.

Richards, Ellen H. S., and Sophronia M. Elliott. 1907. Chemistry of Cooking and Cleaning. Third edition. Boston: Whitcomb \& Barrows.

Richards, Ellen H. S., and Marion, Talbot, eds. 1887. Home Sanitation: A Manual for Housekeepers. Boston: Ticknor.

Reid, Margaret G. 1938. Consumers and the Market. New York: Crofts.

Shapiro, Laura. [1986] 2009. Perfection Salad: Women and Cooking at the Turn of the Century. Berkeley: University of California Press.

Sklar, Kathryn K. 1976. Catharine Beecher: A Study in American Domesticity. New Haven and London: Yale University Press.

Stage, Sarah. 1997a. "Introduction. Home Economics: What's in the Name?" In Sarah Stage and Virginia B. Vincenti, eds., Rethinking Home Economics: Women and the History of a Profession. Ithaca: Cornell University Press, pp. 1-13.

_. 1997b. "Ellen Richards and the Social Significance of the Home Economics Movement." In Sarah Stage and Virginia B. Vincenti, eds., Rethinking Home Economics: Women and the History of a Profession. Ithaca: Cornell University Press, pp. 17-33.

Stage, Sarah, and Virginia B. Vincenti, eds. 1997. Rethinking Home Economics: Women and the History of a Profession. Ithaca: Cornell University Press.

Stanley, Louise. 1923. "Plans for the Bureau of Home Economics." Journal of Home Economics 15 (12): 679-683. 
Stapleford, Thomas A. 2004. "'Housewife vs. Economist': Gender, Class, and Domestic Economic Knowledge in Twentieth-Century America." Labor 1 (2): 89-112.

- 2007. "Market Visions: Expenditure Surveys, Market Research, and Economic Planning in the New Deal." Journal of American History 94 (2): 418-444.

Sutherland, Serenity. 2017. "Discovering Science for Women: The Life of Ellen Swallow Richards, 18421911." PhD diss., University of Rochester.

Swallow, Pamela C. 2014. The Remarkable Life and Career of Ellen Swallow Richards: Pioneer in Science and Technology. New York: J. Wiley \& Sons.

Sworakowski, Witold S. 1979. "Launching the American Food Administration, 1917." In Lawrence Emerson Gelfand, ed., Herbert Hoover: The Great War and Its Aftermath, 1914-23. Iowa City: University of Iowa Press, pp. 40-60.

Tomes, Nancy. 1997. "Spreading the Germ Theory: Sanitary Science and Home Economics, 1880-1930." In Sarah Stage and Virginia B. Vincenti, eds., Rethinking Home Economics. Ithaca: Cornell University Press, pp. 34-54.

Trezzini, Attilio. 2012. "Relative Income vs. Permanent Income: The Crisis of the Theory of the Social Significance of Consumption." Journal of the History of Economic Thought 34 (3): 355-377.

- 2016. "Early Contributions to the Economics of Consumption as a Social Phenomenon." European Journal of the History of Economic Thought 23 (2): 272-296.

van Velzen, Susan. 2001. Supplements to the Economics of Household Behavior. Amsterdam: Thela Thesis. - 2003. "Hazel Kyrk and the Ethics of Consumption." In D. K. Barker and E. Kuiper, eds., Toward a Feminist Philosophy of Economics. New York: Routledge, pp. 38-55.

Veblen, Thorstein B. 1899. The Theory of the Leisure Class. New York: Macmillan.

Waite, Warren C. 1928. The Economics of Consumption. New York: McGraw-Hill Book Company.

Walker, Amasa. 1866. The Science of Wealth: A Manual of Political Economy. Boston: Little, Brown \& Company.

Walker, Francis A. [1883] 1896. Political Economy. Third edition. New York: Henry Holt and Company.

Weigley, Emma S. 1974. "It Might Have Been Euthenics: The Lake Placid Conferences and the Home Economics Movement.” American Quarterly 26 (1): 79-96.

Wilkinson, Laura S. 1895. "National Household Economic Association.” American Kitchen Magazine 4 (3): 133-137.

Williams, Nicholas J. P. 2019. "Becoming What You Eat: The New England Kitchen and the Body as a Site of Social Reform." Journal of the Gilded Age and Progressive Era 18 (4): 441-460.

Winchell, Cora M. 1925. "Open Forum: In Honor of Ellen H. Richards.” Journal of Home Economics 17 (12): 715-717.

Witkowski, Terrence H. 2018. A History of American Consumption: Threads of Meaning, Gender, and Resistance. London: Routledge.

Yi, Yun-Ae. 1996. "Margaret G. Reid: Life and Achievements." Feminist Economics 2 (3): 17-36.

Yonay, Yuval P. 1998. The Struggle over the Soul of Economics: Institutionalist and Neoclassical Economists in America between the Wars. Princeton: Princeton University Press. 